\title{
Study of Creating Incentive Mechanism for Teachers in Private Universities
}

\author{
Yang Guo ${ }^{1, a}$, Kexin Zhang ${ }^{1, b}$ and Xin Dai ${ }^{1, c}$ \\ 1 Jilin Huaqiao University of Foreign Languages, Changchun 130117, China \\ a1044145815@qq.com, ${ }^{b} 574915363 @ q q . c o m,{ }^{c} 305496625 @ q q . c o m$
}

\begin{abstract}
Keywords: Private University, Incentive mechanism, Flexible management, Participation incentive, Emotional incentive
\end{abstract}

\begin{abstract}
Teachers of private universities, as disadvantaged groups, can not enjoy the preferential treatment. Low wages and little welfare can not meet the teachers' basic demands with the rapid economic development and the improvement of people's living standards. Especially the current incentive mechanism of many private universities lags behind, which makes part of teachers have no sense of belonging. Therefore, this paper studies the methods of creating incentive mechanism and gives realistic implementation schemes, which can promote the further development of private universities.
\end{abstract}

\section{Introduction}

In recent years, China's education develops rapidly, and private universities have been stronger and stronger. Independent colleges, as the representation, have mushroomed to expand the running scale and enroll increasing students. The elites from private universities play an important role in every field [1].

Such large scale of students needs more teachers. The outstanding doctors and masters from higher teaching institutions devote themselves to the education career of the private universities. At the same time, the trained students in private universities may become the masters and doctors in the key universities. So win-win situation can form [2].

However, in the education system of private universities, the incentive mechanism of teachers is not perfect, which reduces the teachers' enthusiasm and is harmful to the development of private education. So creation of incentives mechanism is meaningful.

There are many related literature. ZHAO Gui-gui studied the incentive mechanism of middle-young aged teachers [3]. ZHU Hai-ping presented the view that to better the incentive measures for teachers in private colleges and universities, the material rewards for teachers should be raised, their career planning should be nailed down, their experience of achievements should be enhanced, and their predominant status should be consolidated [4]. In order to guarantee and improve the quality of teaching and provide better support for the development of private universities, private universities should put greater emphasis on the establishing of incentive mechanism and stimulate teachers' enthusiasm by a variety of scientific and reasonable means [5]. Colleges and universities firstly should build the concept of service-oriented administration and then work hard to set up professional team, perfect and improve relevant rules and regulations, and establish proper assessment mechanism, so as to establish service-oriented administrative management mode in colleges and universities [6]. In order to make effective motivation measures and decrease dropout rate, universities should make relevant motivation measures, and make sure developing goals of teachers is consistent with long-term goals of universities [7].

Increase Material Incentive and Pay Attention to Spiritual Incentive. Material incentive can greatly arouse the teachers' enthusiasm of work. And spiritual incentive is indispensable to teachers who can have sense of honor after making some achievements. Fig.1 shows the diagram of the material incentive and spiritual incentive. 
Improve Material Incentive and Maximize Material Satisfaction. A person's survival and development can not be separated from the material support, and a private university development is largely dependent on the faculty, not the vast scale of the campus. But the development of private teachers is also relied on the advancement of material condition. In this way, teachers have the passion to teach the students well. In fact the teachers of private universities have gained reasonable material incentive, such as wages, benefits, allowances, bonuses and other aspects, which results in teachers' low work enthusiasm and efficiency.

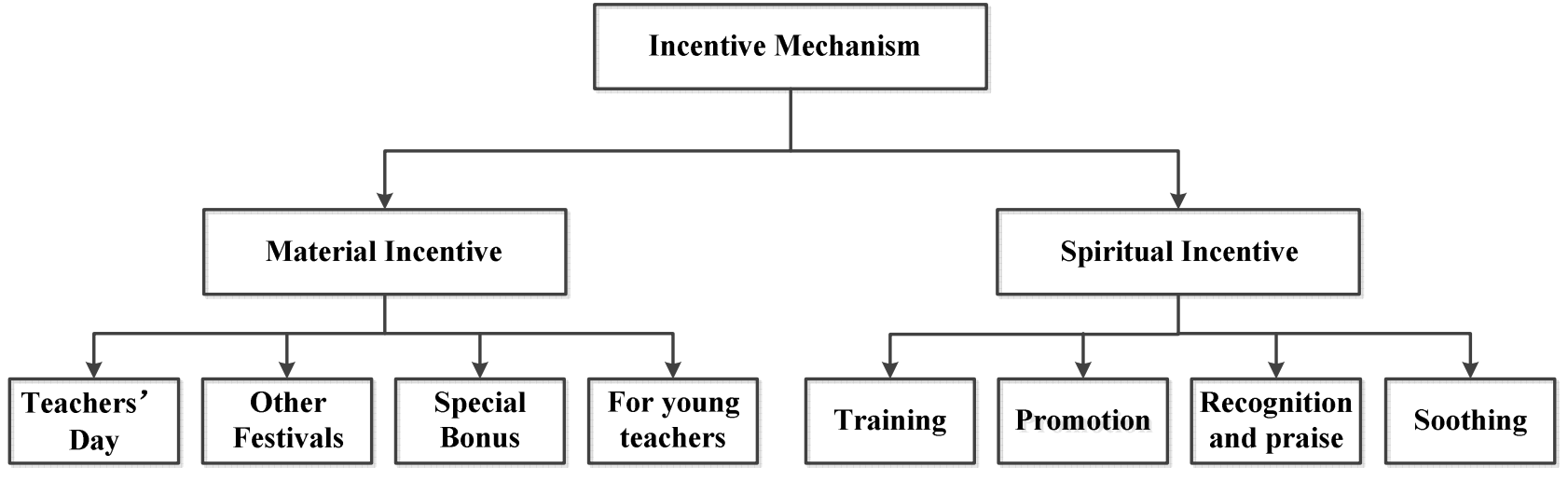

Fig. 1 The diagram of the material incentive and spiritual incentive.

Private universities should build their own features of the material reward mechanism. The purpose of the work of private teachers is to obtain wages for their families. When material condition meets teachers' needs, they can develop themselves to do valuable contributions for their universities. Private universities with great autonomy are not under the jurisdiction of the system. Therefore, private universities should create the wage standard and bonus form in term of local economic development, price level and folk custom. Sometimes some gifts as the bonus can be issued to the teachers according to the local custom. The cohesive force can be enhanced as a means of motivation. In addition, it is vital to improve the accommodation conditions of teachers, especially young teachers facing large economic pressure at the beginning of work. Colleges and universities can distribute the welfare houses to relieve the stress of the young teachers so that they can live at ease. Private universities can set up a dinning room with good environment and low price for teachers. In the Teacher's Day and other major national festivals, teachers can share a rich banquet, which is a great incentive and comfort. Teacher devote themselves to their work and make brilliant successes after acquiring the generous treatment.

Enhance the Spirit Incentives to Make Private Teachers Get Satisfied with the Psychological Benefits. Sometimes, spiritual incentives are more important than material ones. Spiritual incentives are often reflected from the minutia, generally not obvious. When teachers are unfairly treated or their family lies in the adverse circumstances, the university leaders should seize the opportunities, sympathize with compassionate teachers at a critical time. The teachers can repay the university positively. As Maslow's five levels of demand need say that the highest self-fulfilling need is exactly realized from the spirit incentives. Except the basic spiritual incentive, certain encouragement and recognition are also essential. Especially for those outstanding teachers made the achievements, the spirit of praise is imperative. So spiritual incentive is an important part of the incentive mechanism.

However, the psychological development of private teachers can not just depend on the material incentives and general spiritual incentives. After making certain achievements, they tend to pursue their own social status, that is, the so-called self-realization need which is also the highest level of demand in the five levels. In this respect, universities should promptly adjust the positions and posts of excellent teachers, so that they can realize their ego value by virtue of hard work and endeavor.

At the same time in the summer and winter vacations a variety of training courses should be set up for the teachers to upgrade themselves. The related leaders should listen to the teachers' views and suggestions, promptly implement some beneficial policies and measures, construct the proper 
platforms, provide better research condition, and let the teachers work in the higher self-fulfilling environment. In the training education work, the universities may combine the key training and the overall quality improvement as the principle, optimize the whole teacher structure as the goal, take the backbone of middle-aged and young teachers as the emphasis. Encourage and support young teachers to study for doctorate master's degree, participate in domestic and international academic conferences, seminars and workshops. Send visiting scholar at home and abroad, improve teachers' level of knowledge of literacy, education degree, professional teaching and scientific research ability, cultivate competitive academic leaders and the backbone of middle-aged and young teachers. The teachers can access to the forefront of the country, even the international scientific research fields, so they can improve themselves and do more valuable work for the private universities.

\section{On the Premise of Rigid Management, and Dependent on Humanistic Care.}

Rigid management emphasizes strict planning and control, takes the vertical and highly centralized means, and uses regulations and policies as criterion. In contrast, flexible management emphasizes multiple dimensions and flexibility, focusing on the psychological and behavioral needs of human. Flexible management, on the premise of respecting the personal independence and dignity, mainly enhances the cohesion and the sense of belonging to an organization. Actually, it embodies the people-centered management and decentralized concept. As one of new management modes, flexible management pays more attention to the inner world of subordinates, that is, human nature, emotion and spirit. It adopts non-mandatory way, not relying on external forces, but relying on people-oriented fair and impartial management idea, from the heart to stimulate people's internal potential and multifaceted work enthusiasm.

As mentioned above, the development of private teachers requires spiritual incentives, and spiritual incentives are often reflected in the management of human nature. Teachers and leaders need to communicate and interact, strengthen the trust and understanding, and do not need confrontation and tough. No matter what kind of teacher problems to deal with, the university leaders should put down their posts, and actively understand the needs of teachers, so that teachers can dare to tell their true thoughts, which is favorable to the sustainable development of private universities. Loose organizational culture is the premise of organizational flexibility, so the humanized flexible management is also the basic condition for the creation of incentive mechanism.

\section{Conclusion}

The development of private universities is getting more and more prosperous, and the wages of teachers are also rising. Only to strengthen the incentive mechanism of innovation and creation, is an important condition ensuring the continuous development of private universities. Hope that the leaders of private universities can recognize this, and timely feed back on incentive mechanism of private university teachers, which is the only way.

\section{References}

[1] YANG Cong-li: Main Countermeasures of Incentive Mechanism for Full-time Middle-young Aged Teachers in Private Universities [J]. Journal of Changchun Normal University. Vol 32, pp. 90-94, Mar 2013.

[2] WEI Dong-ting: Study of Salary Incentive Agent in Private College [J]. Journal of Guangdong Polytechnic Normal University. No. 5, pp. 136-138, May 2015.

[3] Zhao Gui-gui and Meng Qing-chun: The Study of Incentive Mechanism of Young Teachers in Private University [J]. Journal of Shandong Agricultural Engineering College. Vol. 33, pp. 61-62, Apr 2016.

[4] ZHU Hai-ping: Thought on the Incentive Measures for Teachers in Private Colleges and Universities [J]. Journal of Beijing City University. No. 1, pp. 1-4, Apr 2012. 
[5] DENG Chun: On Establishing Incentive Mechanism for Teachers-- A Case Study of Private Universities [J]. Journal of Guizhou College of Finance and Economics. No. 3, pp. 83-85, Apr 2012.

[6] Dai Wei-zhen: The Reflection of Establishing Service-oriented Administrative Management Mode in Colleges [J]. Journal of Minxi Vocational and Technical College. Vol. 14, pp. 87-90, Jun 2012.

[7] WU Chan-ti and TONG Xue-ming: On Developing Motivation Mechanism of High-level Teachers in Private Universities [J]. Journal of Ningbo University. Vol. 33, pp. 72-75, Nov 2011. 